Article

\title{
Coupling of Cell Division and Differentiation in Arabidopsis thaliana Cultured Cells with Interaction of Ethylene and ABA Signaling Pathways
}

\author{
Galina V. Novikova *, Natalia S. Stepanchenko, Anna A. Zorina, Alexander V. Nosov, \\ Victor Y. Rakitin, Igor E. Moshkov and Dmitry A. Los *D
}

K.A. Timiryazev Institute of Plant Physiology, Russian Academy of Sciences, Botanicheskaya Street 35, Moscow 127276, Russian; stepashka.nt@gmail.com (N.S.S.); tarlonc@yandex.ru (A.A.Z.); alexv.nosov@mail.ru (A.V.N.); rakit@ippras.ru (V.Y.R.); ie.moshkov@mail.ru (I.E.M.)

* Correspondence: gv.novikova@mail.ru (G.V.N.); losda@ippras.ru (D.A.L.)

Received: 2 January 2020; Accepted: 7 February 2020; Published: 10 February 2020

\begin{abstract}
Recent studies indicate direct links between molecular cell cycle and cell differentiation machineries. Ethylene and abscisic acid (ABA) are known to affect cell division and differentiation, but the mechanisms of such effects are poorly understood. As ethylene and ABA signaling routes may interact, we examined their involvement in cell division and differentiation in cell tissue cultures derived from several Arabidopsis thaliana plants: wild type (Col-0), and ethylene-insensitive mutants etr1-1, ctr1-1, and ein2-1. We designed an experimental setup to analyze the growth-related parameters and molecular mechanisms in proliferating cells upon short exposure to ABA. Here, we provide evidence for the ethylene-ABA signaling pathways' interaction in the regulation of cell division and differentiation as follows: (1) when the ethylene signal transduction pathway is functionally active (Col-0), the cells actively proliferate, and exogenous ABA performs its function as an inhibitor of DNA synthesis and division; (2) if the ethylene signal is not perceived (etr1-1), then, in addition to cell differentiation (tracheary elements formation), cell death can occur. The addition of exogenous ABA can rescue the cells via increasing proliferation; (3) if the ethylene signal is perceived, but not transduced (ein2-1), then cell differentiation takes place-the latter is enhanced by exogenous ABA while cell proliferation is reduced; (4) when the signal transduction pathway is constitutively active, the cells begin to exit the cell cycle and proceed to endo-reduplication (ctr1-1). In this case, the addition of exogenous ABA promotes reactivation of cell division.
\end{abstract}

Keywords: Arabidopsis thaliana; abscisic acid; cell culture; cell differentiation; cell proliferation; ethylene

\section{Introduction}

The structure and function of major signaling hubs for intracellular plant growth regulators is one of the longstanding biological questions. In plants, cells divide when triggered by extracellular or intracellular stimuli, including phytohormones. Proliferative signals flow through intracellular signaling pathways to activate the cell cycle. Therefore, cells rely on proliferative signaling pathways to regulate entry into the cell cycle.

Plant growth, which depends on cell division as one of the critical processes, is regulated by several hormones. Taking this into account, one can assume that regulation of the cell cycle is a result of cross-talk of hormone signal transduction pathways. It is generally accepted that phytohormones are common regulators of cell cycle, with auxins and cytokinins being the most extensively documented [1], while the significance of ethylene and abscisic acid (ABA) in this process is still a matter of debate, and there are no data on the cross-talk of signaling pathways of these hormones in regards to cell proliferation. 
It is known that, in stressed intact plants, ethylene and ABA influence each other's synthesis [2], and their signal transduction paths can cross-talk [3-5]. However, there is no information on interaction of the signaling pathways for ethylene and ABA in non-stressed plants.

Previously, we demonstrated that cell tissue culture derived from Arabidopsis thaliana, both wild type and ethylene insensitive mutants, is an appropriate model to study ethylene and ABA effects on cell division under non-stressed conditions [6].

It is fair to say that more is known about ethylene signal perception and transduction than signal perception and transduction for any another plant hormone. The data on ethylene signaling are generated mostly from experimental work on ethylene sensitivity mutants. Using the mutants and identifying the genes where the lesions are, the ethylene transduction chain has been revealed. These involve five partially functionally redundant receptors, localized in the endoplasmic reticulum (ER) and Golgi membrane: ERS1 (ETHYLENE RESPONSE SENSOR 1), ERS2, ETR1 (ETHYLENE RESISTANCE 1), ETR2 and EIN4 (ETHYLENE INSENSITIVE 4). Downstream from the ethylene receptors, there is CTR1 (Constitutive Triple Response 1), a protein homologous to MAPKKK of Raf-type. One particular feature of the ethylene signaling pathway is that the receptors and CTR1 are negative regulators. In a free form, the receptors are bound to CTR1 and this module is permanently in an 'ON' state, suppressing ER-localized downstream protein EIN2, which may be an ion transporter, and transcription activators from EIN3 series. Upon ethylene binding, the receptors and CTR1 are switched 'OFF', which releases the rest of the pathway from inhibition, thus initiating ethylene responses [7].

Genetic screens have identified many mutants with an altered response to exogenous ABA. These approaches have led to a complex and unexplainable pattern of signal transduction. The hunt for ABA receptors succeeded with a new family of proteins called REGULATORY COMPONENTS OF ABA RECEPTOR (RCAR)/PYRABACTIN RESISTANCE1 (PYR1)/PYR1-LIKE (PYL), and a number (clade A) of protein phosphatases of type 2C (PP2C), which function as coreceptors [8,9]. When ABA binds to the receptors, the active site of PP2C is blocked and three associated sucrose non-fermenting-1 (SNF1)-related protein kinase 2s (SnRK2s) are released from PP2C inhibition [10-13]. Then, SnRK2s auto-activates and can subsequently phosphorylate and activate downstream transcription factors, such as ABA-RESPONSIVE ELEMENT (ABREs)/ABRE-BINDING FACTORS (ABFs), to initiate transcription of the stress-responsive and/or ABA-responsive genes controlled by the SnRK2s $[14,15]$. In multicellular organisms, cell division is strictly regulated to avoid uncontrolled cell proliferation, as well as to allow cells to escape from the cell cycle in order to differentiate in accordance with their developmental program. The eukaryotic cell cycle is composed of four well-defined phases, G1, S, G2 and mitosis (M). Progression through the cell cycle is strictly regulated, especially during transitions from the G1 phase to $\mathrm{S}$ phase, from $\mathrm{G} 2$ phase to $\mathrm{M}$ and when leaving $\mathrm{M}$ to return to G1. Most eukaryotic cells divide only in the presence of mitogens, triggering cells to pass through this control point of the G1/S cell cycle. Although the core cell cycle machinery is rather conserved in both animals and plants [16], the nature of the mitogens, as well as the associated signaling pathways, differ substantially.

There is evidence that ethylene and ABA can act as mitogens. It was shown that ethylene inhibited the replication of nuclear DNA and cell division in pea seedlings [17] and induced programmed cell death at particular phases of the cell cycle in tobacco TBY-2 cell line [18]. In addition, ethylene caused endoreduplication [19], and also stimulated the division of stem cells of quiescent center in root meristem of Arabidopsis [20] and cambial cells of poplar [21], together with the cells of quiescent center in maize roots after the excision of the root tip [22]. During osmotic stress, a cell cycle arrest was observed in A. thaliana leaves in parallel with an increase in 1-aminocyclopropane-1-carboxylate (ACC) levels and activation of ethylene signaling [23].

Treatment of cultured BY2 cells with ABA arrested the cells between G1 and S, but did not affect other phases of the cell cycle [24]. It should be emphasized that ABA treatment of alfalfa leaves reduced the positive effect of auxin and cytokinins on cell division [25]. ABA generated during abiotic stresses in the roots of Arabidopsis decreased the number of divisions [26]. In ABA-deficient mutants of 
Arabidopsis, aba2/gin1, the growth of cotyledons, rosettes, stems, roots, and pods was markedly retarded under non-stressful conditions, while ABA treatment stimulated the growth [27]. Similar results were obtained for ABA-deficient mutants of tomato [28].

The Arabidopsis leaves at a very early stage, in which cells are proliferating only, are extremely small. Thus, it is technically challenging to analyze the molecular basis of ethylene/ABA-induced cell division with a sufficient developmental and temporal resolution. We designed an experimental setup to enable a simultaneous analysis of growth-related parameters and molecular mechanisms specifically in the proliferating cells upon short-time exposure to ABA. In our study, Arabidopsis cell suspension cultures have been used as a model to avoid the problems associated with the analyses of intact plants. Here, we show that cell cultures are suitable for identifying the differential roles of ABA and ethylene in cell proliferation and differentiation. We also demonstrate that the functional activity of proteins that perceive and transduce the ethylene signal determines the relationship between proliferation, differentiation, and cell death, and the latter can be reversed by ABA.

\section{Materials and Methods}

Plant material and cell culture treatments. Four genotypes of Arabidopsis thaliana (L.) Heynh of heterotrophic suspension cultures, namely, wild type (ecotype Columbia, Col-0), constitutive triple response1-1 (ctr1-1) mutant, ethylene resistant1-1(etr1-1) and ethylene insensitive2-1 (ein2-1) mutants were used. Suspension cell cultures were generated from the plants by A.V. Nosov and deposited into the All-Russia Collection of Cultivated Cells of Higher Plants (http://www.ippras.ru/cfc/alccmp/).

Cell lines were cultured in the dark in 50-mL Schenk and Hildebrandt medium [29] supplemented with 3\% sucrose, $1 \mathrm{mg} / \mathrm{L}$ 2,4-Dichlorophenoxyacetic acid (2,4-D; Sigma, St. Louis, MO, USA) and $0.1 \mathrm{mg} / \mathrm{L}$ kinetin (Sigma). The cell cultures were agitated on a rotary shaker at $110 \mathrm{rpm}$ at $26^{\circ} \mathrm{C}$ and $70 \%$ humidity in the dark. At 10 day intervals, a $5 \mathrm{~mL}$ aliquot of each culture was transferred to a fresh medium. The growth of suspension cultures was determined by a gravimetric method.

On the 4th day of subculture, cells were treated for 3 hours with a final concentration of either $25 \mu \mathrm{M}$ ABA or $150 \mu \mathrm{M}$ 5-bromo-2'-deoxyuridine (Bromodeoxyuridine, BrdU), which is a synthetic analog of thymidine. When a mutual effect of ABA and BrdU was studied, the cell cultures were treated first with ABA for one hour, then BrdU was added, and cultures were incubated with both substances for another two hours. After that, the cells were collected by centrifugation for $5 \mathrm{~min}$ at $1400 \times g$, frozen in liquid nitrogen and stored at $-70^{\circ} \mathrm{C}$.

Microscopic analysis of living cells and tracheary elements (TE). Cells viability was estimated by the number of cells unstained with $0.02 \%$ aqueous solution of Erythrosin B (Sigma-Aldrich, USA). Both living cells and tracheary elements (TEs) were counted using a Fuchs-Rosenthal chamber. Observation of a secondary wall thickening under a light microscope allows TEs to be easily detected [30].

The incorporation of BrdU into genomic DNA isolated from cultured cells using the GenElute Plant Genomic DNA Miniprep Kit (Sigma) was quantified as previously described [31]. Genomic DNA $(2 \mu \mathrm{g})$ was denatured with $0.4 \mathrm{~N} \mathrm{NaOH}$ and then neutralized by $1 \mathrm{M}$ Tris- $\mathrm{HCl}$ (pH 6.8). A neutralized single-stranded DNA (50 ng) solution was applied to a Hybond-C Extra nitrocellulose membrane $(45 \mu \mathrm{m})$ using a Bio-Dot SF Microfiltration apparatus (Bio-Rad, USA). The membrane was air dried and the DNA was fixed with UV light. The membrane was incubated with mouse monoclonal antibodies against BrdU (Sigma). For visualization, anti-mouse antibodies conjugated with horseradish peroxidase (Promega, USA) were used.

Ethylene emission was determined using a Color 106 Gas Chromatograph (Russia) equipped with a flame ionization detector and a device for concentration of hydrocarbons [32,33].

Determination of ABA content in cultured cells. In order to determine ABA content $0.5-1.5 \mathrm{~g}$ FW of cultured cells were fixed in liquid nitrogen and homogenized in 10 volumes of methanol $\left(-20^{\circ} \mathrm{C}\right)$ containing $10 \mathrm{mg} / \mathrm{L}$ 2,6-Di-tert-butyl-4-methylphenol (Sigma-Aldrich) as an antioxidant. The extract was filtered through a GF/F glass filter (Whatman). The GF/F filter was washed (three times) with $90 \%$ methanol, all filtrates were combined, and vacuum evaporated. 
ABA was purified by anion exchange chromatography on DEAE-Toyoperl $650 \mathrm{M}(9 \times 40 \mathrm{~mm}$, Toyo Soda MGH) equilibrated with $0.25 \mathrm{M}$ potassium acetate after that with $0.2 \mathrm{~N}$ acetic acid, and with $90 \%$ methanol. After filtrate loading, the column was washed with $90 \%$ methanol and finally with deionized water. Then, an anion exchange column was connected to Chromosorb LC-7 (C18) $(6 \times 30 \mathrm{~mm}$, Sigma). ABA was eluted with $0.3 \mathrm{~N}$ acetic acid. Thereafter, this column was washed with $0.004 \mathrm{~N}$ formic acid ( $\mathrm{pH} 3)$ and connected with Sephasorb HP Ultrafine $(4.6 \times 250 \mathrm{~mm}$, Pharmacia). ABA was eluted with $0.003 \mathrm{~N}$ formic acid in $98 \%$ methanol. The ABA retention time was $10 \mathrm{~min}$. The ABA was collected and dried in a nitrogen stream at $40{ }^{\circ} \mathrm{C}$.

The purified dried ABA was methylated by the addition of $200 \mu \mathrm{l}$ of a diazomethane produced from nitrosomethylurea in a diazomethane generator (Wheaton Scientific). The methylation was carried out at $0{ }^{\circ} \mathrm{C}$ for $10 \mathrm{~min}$, the sample was dried at $35^{\circ} \mathrm{C}$ in a nitrogen stream, dissolved in $50 \mu \mathrm{L}$ of hexane, and 1-2 $\mu \mathrm{L}$ was analyzed by gas chromatography.

For the quantification analysis of ABA methyl ester, a gas chromatograph Gasochrome 1109 (Russia) with an electron capture detector with a ${ }^{63} \mathrm{Ni}$ radiation source in an $\mathrm{HP}-17$ column $(0.53 \mathrm{~mm} \times 10 \mathrm{~m}$, Hewlett-Packard) was used. The injector temperature was $275{ }^{\circ} \mathrm{C}$, the detector- $260{ }^{\circ} \mathrm{C}$, and the column $-250^{\circ} \mathrm{C}$. The ABA methyl ester retention time was 6 min.

For $\mathrm{ABA}$ recovery, the internal standard was utilized. As an internal standard 1 pg per $1 \mathrm{~g}$ FW of cultured cells [ $\left.{ }^{3} \mathrm{H}\right] \mathrm{ABA}$ (specific activity $2.55 \mathrm{TBq} / \mathrm{mol}$, Amersham, UK) was applied. Using this purification technique, a 93\%-yield of ABA was achieved.

Isolation of soluble proteins. Cells frozen in liquid nitrogen were homogenized and proteins $(1: 1.5, \mathrm{w} / \mathrm{vol})$ were extracted into $50 \mathrm{mM}$ Tris- $\mathrm{HCl}(\mathrm{pH}$ 7.6), which contained $10 \mathrm{mM} \mathrm{MgCl}, 2 \mathrm{mM}$ EDTA, $1 \mathrm{mM}$ DTT, $1 \mathrm{mM}$ phenylmethylsulfonyl fluoride (PMSF), $1 \mathrm{mM}$ EGTA, $2 \mathrm{mM} \mathrm{Na}_{3} \mathrm{VO}_{4}, 1 \mathrm{mM}$ benzamidine, $10 \mathrm{mM} \mathrm{NaF}, 50 \mathrm{mM} \beta$-glycerophosphate and $250 \mathrm{mM}$ sucrose. Soluble proteins obtained by centrifugation $(130,000 \times g$ for $3 \mathrm{~h}$ ) were desalted by elution with $10 \mathrm{mM}$ Tris- $\mathrm{HCl}(\mathrm{pH} 7.6)$ of NAP-5 columns (GE Healthcare Life Science). Protein content was determined with BCA Protein Assay Kit (Sigma).

Phosphorylation of cytosolic proteins in vitro and visualization of phosphorylated proteins. Phosphorylation reaction was performed in a reaction mixture containing $20 \mathrm{mM}$ Tris- $\mathrm{HCl}(\mathrm{pH} 7.6), 10 \mathrm{mM} \mathrm{MgCl}, 1 \mathrm{mM}$ $\mathrm{MnCl}_{2}, 1 \mathrm{mM}$ EGTA, $1 \mathrm{mM}$ DTT, $1 \mathrm{mM}$ PMSF, $2 \mathrm{mM} \mathrm{Na}_{3} \mathrm{VO}_{4}, 10 \mathrm{mM} \beta$-glycerophosphate, $1 \mathrm{mM}$ benzamidine, $10 \mu \mathrm{M}$ ATP and $18.5 \mathrm{kBq}\left[\gamma^{-32} \mathrm{P}\right] \mathrm{ATP}$ (specific activity $110 \mathrm{TBq} / \mathrm{mmol}$ ) per $1 \mu \mathrm{g}$ protein. The reaction was initiated by $50-150 \mu \mathrm{g}$ of protein and was carried out for $20 \mathrm{~min}$ at $30^{\circ} \mathrm{C}$.

Proteins were precipitated at $-20^{\circ} \mathrm{C}$ with $80 \%$ acetone, purified using a DE CleanUp Kit (Bio-Rad), and dissolved in a buffer containing 7.5 M urea, $2 \mathrm{M}$ thiourea, $1 \%$ Triton X-100, 4\% CHAPS, $20 \mathrm{mM}$ DTT, and $0.2 \%$ BioLyte $3 / 10$ Ampholyte (Bio-Rad). In the first dimension, proteins were resolved using a $7 \mathrm{~cm}$ Immobiline DryStrip gels (IPG strips) $\mathrm{pH} 4-7$, as recommended by GE Healthcare. In the second dimension, denaturing gel electrophoresis was performed [34]. Gels were stained with silver nitrate according [35], dried, and exposed with a Biomax MR film (Kodak, CA, USA).

The in vitro determination of MAP kinase activity was carried out by incubating $10 \mu \mathrm{g}$ proteins for $20 \mathrm{~min}$ at $30{ }^{\circ} \mathrm{C}$ in a reaction mixture containing $0.25 \mathrm{mg} / \mathrm{mL}$ Myelin Basic Protein (MBP) as an exogenous substrate, $20 \mathrm{mM}$ Tris- $\mathrm{HCl}$ ( $\mathrm{pH} 7.6), 10 \mathrm{mM} \mathrm{MgCl}_{2}, 1 \mathrm{mM} \mathrm{MnCl}_{2}, 1 \mathrm{mM}$ EGTA, $1 \mathrm{mM}$ DTT, $1 \mathrm{mM}$ PMSF, $2 \mathrm{mM} \mathrm{Na}_{3} \mathrm{VO}_{4}, 10 \mathrm{mM} \beta$-glycerophosphate, $1 \mathrm{mM}$ benzamidine, $10 \mu \mathrm{M}$ ATP and $37 \mathrm{kBq}$ of $\left[\gamma^{-32} \mathrm{P}\right]$ ATP (specific activity $110 \mathrm{TBq} / \mathrm{mmol}$ ). The reaction was terminated with SDS-PAGE sample buffer. Then SDS-PAGE was carried in a 15\% gel. To visualize phosphorylated MBP, dried stained gels were exposed to a Biomax MR X-ray film (Kodak).

In situ MAP kinase activity was determined in $10 \%$ gel with $0.5 \mathrm{mg} / \mathrm{mL}$ MBP polymerized within the gel. After electrophoresis, the gels were incubated in $20 \%$ isopropanol, $50 \mathrm{mM}$ Tris- $\mathrm{HCl}$ ( $\mathrm{pH}$ 8.0) and $5 \mathrm{mM}$ 2-mercaptoethanol, followed by washing in $50 \mathrm{mM}$ Tris- $\mathrm{HCl}(\mathrm{pH}$ 8.0) with $5 \mathrm{mM}$ 2-mercaptoethanol. Then the proteins were re-denatured with $6 \mathrm{M}$ guanidine hydrochloride in $50 \mathrm{mM}$ Tris- $\mathrm{HCl}$ ( $\mathrm{pH} 8.0$ ) with $5 \mathrm{mM}$ 2-mercaptoethanol. Protein renaturation was performed in $50 \mathrm{mM}$ Tris- $\mathrm{HCl}$ (pH 8.0), 0.04\% Tween 40, and $5 \mathrm{mM} 2$-mercaptoethanol. Then, the gels were preincubated in 
$40 \mathrm{mM}$ Hepes- $\mathrm{NaOH}$ (pH 8.0) containing $2 \mathrm{mM}$ DTT, $10 \mathrm{mM} \mathrm{MgCl} 2,0.1 \mathrm{mM}$ EGTA, and $1 \mathrm{mM} \mathrm{MnCl} 2$. For phosphorylation reaction, the gels were incubated in $40 \mathrm{mM}$ Hepes-NaOH (pH 8.0) containing $40 \mu \mathrm{M}$ ATP, $10 \mathrm{mM} \mathrm{MgCl} 2,1 \mathrm{mM} \mathrm{MnCl}{ }_{2}$ and $74 \mathrm{kBq} / \mathrm{mL}\left[\gamma_{-}{ }^{32} \mathrm{P}\right]$ ATP (specific activity $110 \mathrm{TBq} / \mathrm{mmol}$ ). The reaction was terminated with $5 \%$ TCA with $1 \% \mathrm{Na}_{4} \mathrm{P}_{2} \mathrm{O}_{7}$. The dried gels were exposed with a Biomax MR X-ray film (Kodak).

Fractionation of soluble protein mixtures by Liquid-Phase Isoelectric Focusing. BioLyte 3/10 (Bio-Rad) were mixed with $2.5 \mathrm{~mL}$ soluble protein fraction ( $1.5 \mathrm{mg}$ protein) to a final concentration of $1.5 \%$. The resulting mixture was loaded in an isoelectric focusing column, which was placed between two membranes moistened, respectively, with catholyte $\left(0.1 \mathrm{M} \mathrm{H}_{3} \mathrm{PO}_{4}\right)$ and analyte $(0.1 \mathrm{M} \mathrm{NaOH})$. Focusing was carried out in a MicroRotofor Liquid-Phase IEF Cell (Bio-Rad) according to the manufacturer's protocol at $10{ }^{\circ} \mathrm{C}$, a power of $1 \mathrm{~W}$ and a maximum voltage of $1000 \mathrm{~V}$ until the voltage stabilization. Protein fractions $(200 \mu \mathrm{L})$ were collected using a special device equipped with a vacuum pump. In each of the 10 fractions obtained, the $\mathrm{pH}$ value as well as the protein content were measured [36].

Sample preparation and mass spectrometry. Samples were prepared for mass spectrometry (MS) using in-gel digestion. After the 2D electrophoresis and/or fractionation of soluble protein by Liquid-Phase Isoelectric Focusing proteins were stained with colloidal CBB G-250 [37]. Gel spots/lanes were excised, cut into equally sized bands and each band was further cut into $1 \mathrm{~mm}$ cubes. The gel pieces were destained with $50 \mathrm{mM}$ ammonium bicarbonate in $50 \%(\mathrm{v} / \mathrm{v})$ acetonitrile. Samples were reduced with $10 \mathrm{mM}$ dithiothreitol at $56{ }^{\circ} \mathrm{C}$ for 1 hour and subsequently alkylated with $5 \mathrm{mM}$ iodoacetamide for $45 \mathrm{~min}$ at room temperature in the dark. Gel bits were dehydrated in acetonitrile and dried. Sequencing grade modified trypsin (Promega) in $50 \mathrm{mM}$ ammonium bicarbonate, was added to each gel band $\left(1: 50(\mathrm{w} / \mathrm{w})\right.$ protease protein) and digestion was allowed to proceed at $37^{\circ} \mathrm{C}$ for $16 \mathrm{~h}$. The tryptic digests were analyzed by MS. MS spectra were obtained on a tandem MALDI time-of-flight mass spectrometer Ultraflex II BRUKER (MALDI-TOF MS, Germany) equipped with a UV laser (Nd) in the mode of positive ions in a linear mode, using a reflectron. MS spectra were processed using software (FlexAnalysis 3.3 package, Bruker Daltonics, Germany). Using the Mascot program (peptide fingerprint option, www.matrixscience.com), homologs were searched in the NCBI database among proteins of all organisms. Candidate proteins with a score parameter above 83 in the NCBI database were considered to be reliably determined $(p<0.05)$. A molecular mass search was performed using Biotools 3.0 software (Bruker Daltonics, Germany).

RNA isolation and RT-PCR Analysis. Total RNA was isolated from $100 \mathrm{mg}$ of a cell pellet using the Spectrum Plant Total RNA Kit (Sigma) according to the manufacturer's protocol. Prior to RT-PCR, RNA was additionally purified from DNA by digestion with DNase I (Fermentas, Vilnius, Lithuania). RNA (1 mg) integrity was checked electrophoretically in a $1 \%$ agarose gel.

RT was done using Superscript III transcriptase (Invitrogen, United States). The reaction was carried out as recommended by the manufacturer; the reaction mixture contained $2 \mu \mathrm{g}$ of total RNA and reverse PCR primers, which are listed in Table S1. The resulting cDNA was used as a PCR template.

RT-PCR products were analyzed by electrophoresis in a $1 \%$ agarose gel. For a quantitative analysis the One-Dscan program was used. A difference in the intensity of the bands greater than two times was considered significant.

Statistics. All experiments were performed with at least three independent biological experiments. The means for three analytical replicates and their standard errors (SE) are presented. Figures $2 b, 4$, and 5 show the results of a typical experiment. Comparisons of datapoints from different treatments with controls were performed using Tukey multiple pairwise comparison test. Differences of $p<0.05$ were considered significant. 


\section{Results and Discussion}

\subsection{Assessing the Effects of ABA on Growth and Differentiation in Cell Suspension Cultures}

Actively proliferating cell cultures of wild-type A. thatiana (Col-0) and ethylene-insensitive mutants etr1-1, ein2-1, and ctr1-1 have been established and extensively characterized. Mutant lines are visibly distinguished from Col-0. The cells of ctr1 are significantly bigger than Col-0, and etr1 and ein2 contain many tracheary elements (TEs), i.e., a significant number of cells leave the cell cycle and follow the terminal differentiation. Moreover, in etr1 apart from the TEs formation the cell death has occurred [6]. To assess the effects of ABA, Col-0, etr1-1 and ein2-1 cell cultures were used at day 5 following sub-cultivation, which is the stage when the most of the cells are in S-phase $[6,33,38]$. The cultures were inoculated into a fresh medium with $50 \mu \mathrm{M}$ ABA. Then, growth indices (Is) and the number of TEs were determined. At the end of sub-cultivation, ABA-untreated cells of Col-0, etr1-1 and ein2-1 were similar in terms of Is (Figure 1). When cells were grown in ABA-supplemented medium, Col-0 cells retained $60 \%-70 \%$ viability, while the growth of ein2-1 was not affected by ABA, and etr1-1 behaved quite differently (Figure 1b). The etr1-1 cells partly returned "back to life" which was reflected in a pronounce increase of I value, while the number of TEs was decreased (Figure 1b). These results were opposite to those observed in ein2-1, where the TE number was two to three times higher than in etr1-1. Therefore, we have suggested that both ETR1 and EIN2 are essential for normal cell cycle progression in cultivated cells.

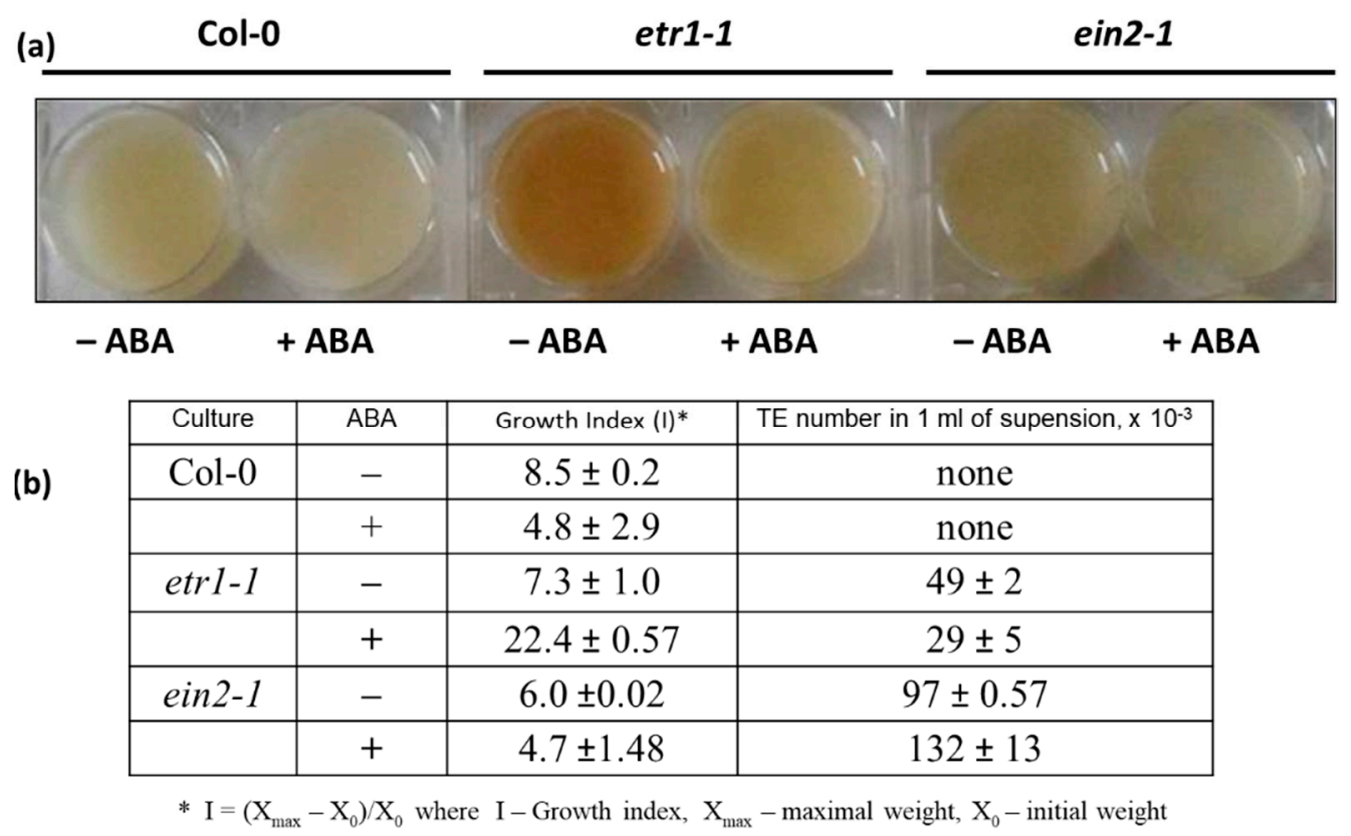

Figure 1. The effect of abscisic acid (ABA) on the phenotype (a) and growth indexes (Is) (b) of suspension cultures of $A$. thaliana Col-0, etr1-1, and ein2-1. Cell cultures of three genotypes were grown in the medium supplemented with $50 \mu \mathrm{M}$ ABA (+ABA) for 10 days. (-ABA): control tissue culture not supplemented with ABA. At the end of sub-culturing, Is values and number of TEs were determined. Values presented are means of three independent experiments with five replicates in each $\pm \mathrm{SE}$ (standard error). Data are significant at $p<0.05$.

A sequence of specific cellular events that lead to cell differentiation is required to form a mature TE and the study of this process in planta is difficult because differentiation occurs within complex tissues in the plant body. Opposite to intact plants, in vitro cell cultures that differentiate into a high percentage of TEs can be assessed at different time points after the induction of TE formation. Examples of successfully established in vitro TE systems include $A$. thaliana [39]. It was previously demonstrated that TE formation in a suspension of Arabidopsis cells can be induced by brassinosteroids [40] and 
inhibited by 2,4-dichlorophenoxyacetic acid (2,4-D). Auxins (especially synthetic 2,4-D, which is commonly used in a culture medium) are known to stimulate ethylene production. Since the etr1-1 and ein2-1 mutants are insensitive to ethylene, but TEs are actively formed in them, it can be assumed that the inhibition of TE formation in these cultures was ethylene- rather than 2,4-D-dependent. At the same time, one cannot ignore the fact that some ethylene-insensitive mutants are characterized by a high content of endogenous $\mathrm{ABA}$, as shown, for example, in etiolated seedlings and intact ein2-1 plants $[4,23,27,28]$. In addition, it has been shown that endogenous ABA in the absence of stress can accelerate growth by inhibiting ethylene synthesis [41,42].

\subsection{Ethylene and ABA Production during the Sub-Cultivation Cycle and Effect of ABA on DNA Synthesis}

Measurement of the content of endogenous ABA in the cell cultures during the subculture period showed that the amount of hormone in etr1-1 and ein2-1 lines tended to increase, while in Col-0 the amount of ABA did not change (Table 1). Based on these data, cells were treated with exogenous $25 \mu \mathrm{M}$ ABA after 4-5 days of inoculation into a fresh medium, when the content of endogenous $\mathrm{ABA}$ was similar in all cultures.

Table 1. The endogenous ABA content (ng/g FW) in suspension tissue cultures Col-0, etr1 and ein2-1 during sub-cultivation. Values presented are means of three independent experiments with five replicates in each $\pm \mathrm{SE}$ (standard error). Data are significant at $p<0.05$.

\begin{tabular}{cccc}
\hline Days & Col-0 & etr1-1 & ein2-1 \\
\hline 2 & $4.3 \pm 0.21$ & $2.9 \pm 0.15$ & $2.4 \pm 0.12$ \\
4 & $4.0 \pm 0.20$ & $3.5 \pm 0.18$ & $2.6 \pm 0.13$ \\
6 & $3.6 \pm 0.18$ & $4.4 \pm 0.22$ & $3.0 \pm 0.15$ \\
9 & $3.3 \pm 0.16$ & $5.6 \pm 0.28$ & $4.8 \pm 0.24$ \\
\hline
\end{tabular}

This data should be considered together with the results on changes in ethylene biosynthesis during the period of subculture (Table 2). Apparently, if ethylene and ABA only affect each other's synthesis in a cell culture, then in Col-0 with a relatively constant level of ABA (Table 1) ethylene synthesis should also remain at a constant level (Table 2). However, the data obtained do not confirm this assumption: the ethylene content in Col-0 cells decreased 17 times between the 4 th and 10th day of subculture. On the 9th day of cultivation, in etr1-1 and ein2-1 lines, the ABA content was almost twice higher than at the day two (Table 2). At the same time, by the end of the sub-cultivation, etr1-1 line synthesized twice as much ethylene, and the ein 2-1 line produced 12 times less ethylene than Col-0. Thus, if ethylene signaling is not interrupted, then ethylene negatively regulates ABA biosynthesis.

Table 2. The effect of exogenous ABA $(50 \mu \mathrm{M})$ on ethylene biosynthesis in suspension tissue cultures Col-0 0, etr1-1 and ein2-1 during sub-cultivation. Values presented are means of three independent experiments with five replicates in each \pm SE (standard error). Data are significant at $p<0.05$.

\begin{tabular}{ccccc}
\hline \multirow{2}{*}{ Cultivation, Days } & \multirow{2}{*}{ ABA } & \multicolumn{3}{c}{ Ethylene Evolution, $\mathbf{n L ~ g}^{\mathbf{- 1}} \mathbf{F W ~ \mathbf { ~ } ^ { \mathbf { - 1 } }}$} \\
\cline { 3 - 5 } & & Col-0 & etr1-1 & ein2-1 \\
\hline \multirow{2}{*}{4} & - & $595 \pm 15$ & $281 \pm 4$ & $18 \pm 3$ \\
& + & $482 \pm 27$ & $288 \pm 18$ & $31 \pm 1$ \\
6 & - & $323 \pm 7$ & $268 \pm 1$ & $12 \pm 2$ \\
& + & $464 \pm 7$ & $266 \pm 23$ & $22 \pm 1$ \\
\multirow{2}{*}{10} & - & $34 \pm 5$ & $82 \pm 45$ & $2.7 \pm 0.04$ \\
& + & $238 \pm 22$ & $66 \pm 27$ & $3.5 \pm 0.25$ \\
\hline
\end{tabular}

In dicots, such as the model species $A$. thaliana, leaves initiate at the flank of the meristem, and, in the initial phase, their growth is driven exclusively by cell proliferation. In older leaves, cells exit the cell cycle and begin to elongate, starting from the tip onward. This transition is marked by the 
onset of endo-reduplication, that is, a modified cell cycle in which DNA replication proceeds without mitosis, resulting in higher ploidy, such as $4 \mathrm{C}$, and $8 \mathrm{C}$. Cell proliferation is influenced by both genetic background and extracellular cues.

It is believed that in many cell types, ABA inhibits division and/or DNA synthesis at the G1/S without affecting other phases of the cell cycle [24]. Considering this data, we analyzed the effect of ABA on DNA synthesis, determining in vivo incorporation of thymidine analog BrdU into DNA. Cell cultures of all genotypes were treated for 1 hour with ABA $(25 \mu \mathrm{M})$. One hour later, BrdU $(150 \mu \mathrm{M})$ was added, and cells were incubated with these two chemicals for two hours. DNA was isolated, denatured and immobilized on a nitrocellulose membrane. The BrdU incorporation into DNA was evaluated immunologically via staining with anti-BrdU antibodies (1:2000 dilution) [31].

In Col-0 culture in the middle of the exponential growth phase, a short ABA treatment caused a decrease in BrdU incorporation into DNA (Figure 2). This can be interpreted as a negative effect of ABA on DNA synthesis, since, in all cell lines used in these experiments, the content of endogenous ABA is similar (Table 2). These results are consistent with the previously reported data [23].

(a)

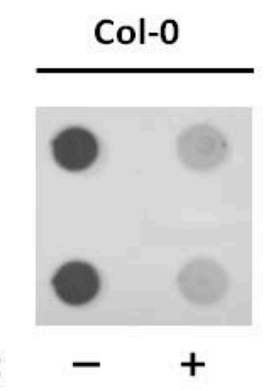

etr1-1

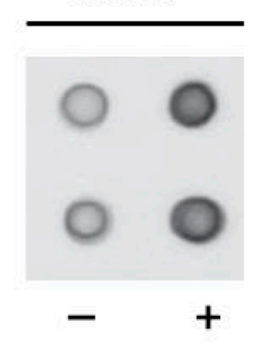

ctr1-1

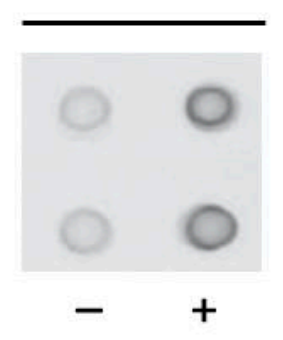

ein2-1

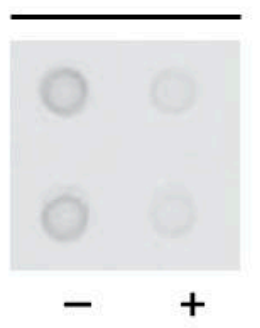

(b)

\begin{tabular}{|c|c|c|c|c|}
\hline Treatment & Col-0 & etr1-1 & ctr1-1 & ein2-1 \\
\hline None & $\mathbf{1 2 0}^{*}$ & $\mathbf{5 5}$ & $\mathbf{6 5}$ & $\mathbf{5 8}$ \\
\hline + ABA & $\mathbf{9 0}$ & $\mathbf{8 5}$ & $\mathbf{7 9}$ & $\mathbf{5 3}$ \\
\hline
\end{tabular}

* Relative BrdU signal intensity, optical density

Figure 2. ABA $(25 \mu \mathrm{M})$ affects 5-bromo-2-deoxyuridine (BrdU) incorporation into the DNA of Col-0, etr1-1, ctr1-1, and ein2-1 cell lines. Genomic DNA $(2 \mu \mathrm{g})$ was isolated from cultured cells and denatured. Single-stranded DNA was applied to Hybond-C using a Bio-Dot SF Microfiltration apparatus (a). BrdU incorporation into DNA was quantified (b) with monoclonal anti-BrdU antibodies (1:2000 dilution). For visualization, anti-mouse antibodies (dilution 1:7000) conjugated with horseradish peroxidase were used. Numbers in (b) correspond to relative BrdU signal intensities quantified as optical density of dot-blots.

Unlike in Col-0, in ABA-treated etr1-1 cell line the BrdU incorporation into the DNA increased significantly, while no ABA effect was found in ctr1-1 and ein2-1 mutant cell lines (Figure 2). Therefore, in in vitro cultured cells, ethylene insensitivity can affect ABA signaling, which normally leads to inhibition of DNA synthesis.

Data on the ABA effect on DNA synthesis should be considered in parallel with the results of determining of mitotic activity. For such a comparison, we will use the data of Stepanchenko et al. [6] that demonstrate that, under standard conditions, the DNA synthesis in the exponential growth phase correlates $(r=0.98)$ with the mitotic activity of suspension cultures.

When the ethylene signal transduction pathway functions normally, as in Col-0, ABA inhibited DNA synthesis (G1/S transition) and did not affect the value of the mitotic index (5.4\%) (Figure 2). Tracheary elements appeared massively only in etr1-1 and ein 2-1 suspensions, i.e., a certain fraction of cells followed the terminal differentiation (TE formation), which probably affected the mitotic activity 
of etr1-1 and ein2-1 cells. Their mitotic indexes were halved to $2.8 \%$ and $2.7 \%$, respectively. In this case, exogenous ABA, in the absence of ethylene signal perception, stimulated DNA synthesis in etr1-1 but not in ein2-1 cultures, where the ethylene signal is perceived but not transferred (Figure 2).

A significant part of ctr1-1 cells was preoccupied by DNA endoreduplication and, probably, was delayed in the G2 phase. Exogenous ABA did not affect DNA synthesis in ctr1-1 cells, but prevented the transition of cells to endo-reduplication, as can be seen from the increase in the mitotic index from $3.5 \%$ to $4.3 \%$.

\subsection{ABA Affects Soluble Proteins Phosphorylaion in Col-0 and Ethylene-Insensitive Mutant Cell Cultures}

Despite the unique fate of cells in etr1-2, ctr1-1, and ein2-1 cultures, all three cell lines can be stably maintained in vitro, which indicates the unaffected functioning of cyclin-dependent protein kinases that ensure progression through the cell cycle. We focused on the search for proteins whose functions do not duplicate the steps of the universal cyclin-dependent cell cycle machine.

Extensive research in Arabidopsis led to the identification of key elements in the ethylene and ABA signaling cascade. Since mitogen-activated protein kinases (MAPKs) are components of the ethylene and ABA signaling [43-49], we assumed that the effect of these phytohormones could be associated with changes in the enzymatic activity of these protein kinases. As the MKK9-MPK3/MPK6 cascade is involved in not only in ethylene biosynthesis, but also ethylene signaling acting downstream of CTR1 [46] to make sure that mitogen-activated protein kinase kinase (MKK) can be found among ABA-regulated phosphoproteins, the cells were first treated with a specific MKK inhibitor, U0126, and then with ABA. Proteins isolated from U0126-treated cells demonstrated a decrease in the phosphorylation level of MBP, indicating the presence of MPK, the specific substrate for MKK (Figure 3).

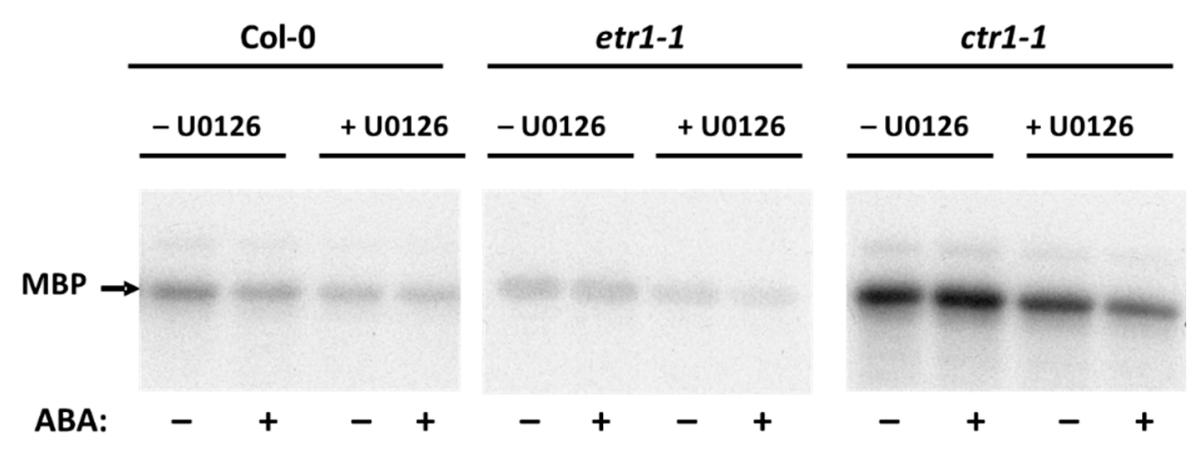

Figure 3. Effect of U0126 protein kinase kinase (MKK) inhibitor on ABA-dependent MBP-phosphorylation of the soluble proteins isolated from Col-0, etr1-1, and ctr1-1 cultures. Soluble proteins were isolated from ABA/U0126-untreated cells and treated with both substances. Myelin basic protein (MBP) phosphorylation was tested in vitro with $\left[\gamma_{-}{ }^{32} \mathrm{P}\right]$ ATP. Radioautographic image is presented.

\subsection{The Effect of $A B A$ on Transcription of Individual MPK Genes}

It is known that, in tobacco BY-2 cell culture, high activity of mitotic cyclin-dependent protein kinases is required for the phosphorylation of nucleus- and phragmoplast-localized protein kinase 1 (NPK1) and NPK1-activating kinesin-like protein 1 (NACK1), and that this phosphorylation inhibits the MAPK cascade, thereby preventing M phase cells from initiating cytokinesis before anaphase [50]. If $\mathrm{ABA}$ is able to regulate proliferation, can this effect be associated with changes in MPK activity, especially since there is evidence of ABA regulation of MPK activity [49]? To answer this question, all the cell cultures in the phase of exponential growth were incubated with $25 \mu \mathrm{M}$ ABA for three hours (Table 3). The concentration of exogenous ABA and the exposure time were chosen to avoid affecting the ethylene biosynthesis. 
Table 3. Ethylene evolution (nL/g FW/h) by cell cultures Col-0, etr1-1 and ctr1-1 treated with ABA ( $25 \mu \mathrm{M})$ for three hours. Values presented are means of three independent experiments with five replicates in each \pm SE (standard error). Data are significant at $p<0.05$.

\begin{tabular}{ccc}
\hline Culture & Untreated & ABA Treated \\
\hline Col-0 & $280 \pm 6$ & $250 \pm 12$ \\
etr1-1 & $160 \pm 6$ & $150 \pm 8$ \\
ctr1-1 & $130 \pm 8$ & $200 \pm 20$ \\
\hline
\end{tabular}

As it was demonstrated earlier, the application of exogenous ABA resulted in the regulation of the transcription, protein accumulation and activation of MPKs [51-58]. In order to analyze the effect of ABA on the expression of MPKs, we selected genes encoding MPKs belonging to the three MPK groups, namely, MPK3 and MPK6 belonging to group A, MPK4 and MPK5 to group B, and MPK1 and MPK2 to group C [58].

Using RT-PCR, we found that during the exponential growth phase of Col-0, etr1-1, and ein2-1 cultures, the constitutive level of MPK4 transcription was higher than that of other MPKs genes and depended on the treatment with exogenous ABA in Col-0 only (Figure 4). On the contrary, the MPK1 and MPK2 genes were transcribed at an extremely low level, which coincides with the literature data [59].

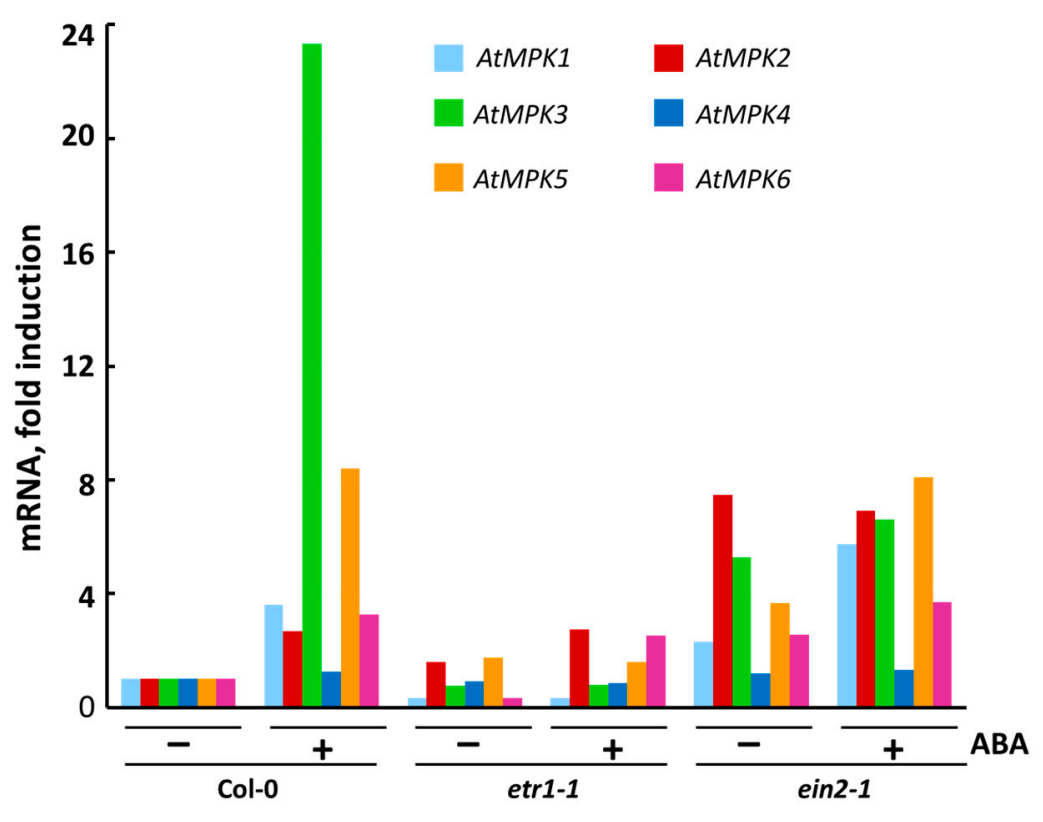

Figure 4. Expression of individual genes coding for MPKs in Col-0, etr1-1, and ein2-1 cultured cells after $3 \mathrm{~h}$ treatment with ABA. mRNA levels in cultured Col-0, etr1-1 and ein2-1 cells were examined by RT-PCR. For RT-PCR analysis, AtACT2 was used as a reference gene. Data on a typical experiment are presented.

After ABA treatment, MPK1 expression increased in Col-0 and ein2-1, while MPK2 transcription increased significantly in both Col-0 and etr1-1, but did not change in ein2-1. Although the MPK1 and MPK2 proteins are $87 \%$ identical, their sensitivity to ABA can vary. It cannot be ruled out that, in the same interval of treatment with exogenous $\mathrm{ABA}$, the maximum activation of expression of MPK1 occurs earlier than in the case of MRK2. Therefore, it can be assumed that MPK1 in proliferating cells is associated with ABA signal transduction. This assumption is important, given that there are known differences in the time-dependent activation of MPK1 and MPK2 [59].

In the Col-0 and ein 2-1 cell lines, MPK5 expression was doubled after treatment with ABA, whereas, in etr1-1, ABA had no effect on MPK5 expression. MPK3 expression was highly induced in ABA-treated 
Col-0, while in etr1-1 and ein2-1 it was extremely low and ABA-independent. In ABA-treated Col-0, MPK6 expression was more than three times higher compared to the control cell culture. On the contrary, in ein2-1, MPK6 transcription was ABA independent, since the activation was only 1.4 times higher after ABA treatment. However, in etr1-1 cells, ABA treatment significantly affected MPK6 expression (more than seven times) (Figure 4). Since etr1-1 does not perceive ethylene due to a mutation in the ethylene receptor ETR1, ABA should be considered responsible for the detected change in the level of MPK6 expression in etr1-1.

\subsection{The Effect of ABA on Transcription of Individual SnRK2 Genes}

It is currently accepted that, in plants, signaling events involving ABA begin with the biosynthesis of the hormone, their long-distance transport, followed by the perception of ABA by their receptors and the initiation of the ABA signal transduction pathway [8,9,12]. Protein phosphatases PP2C (Group A) and the SnRK2 protein kinases are the key components of the ABA-signaling pathway, initiated after the binding of ABA to the receptors.

In Arabidopsis, there are 10 protein kinases of the SnRK2 family, which are divided into three subfamilies [60]. However, only SnRK2.2/2.3/2.6/2.7/2.8, belonging to subfamily III, were activated by ABA $[3,11,61,62]$ with the highest sensitivity to ABA found for SnRK2.2/2.3/2.6 [3,63,64].

We studied the effect of a three-hour treatment with exogenous ABA on the expression of the SnRK2.2, SnRK2.3 and SnRK2.6 in Col-0 and ethylene-insensitive mutant cell cultures (Figure 5). We found that in all untreated cultures the level of $S n R K 2.3$ expression was strongly ABA-regulated.

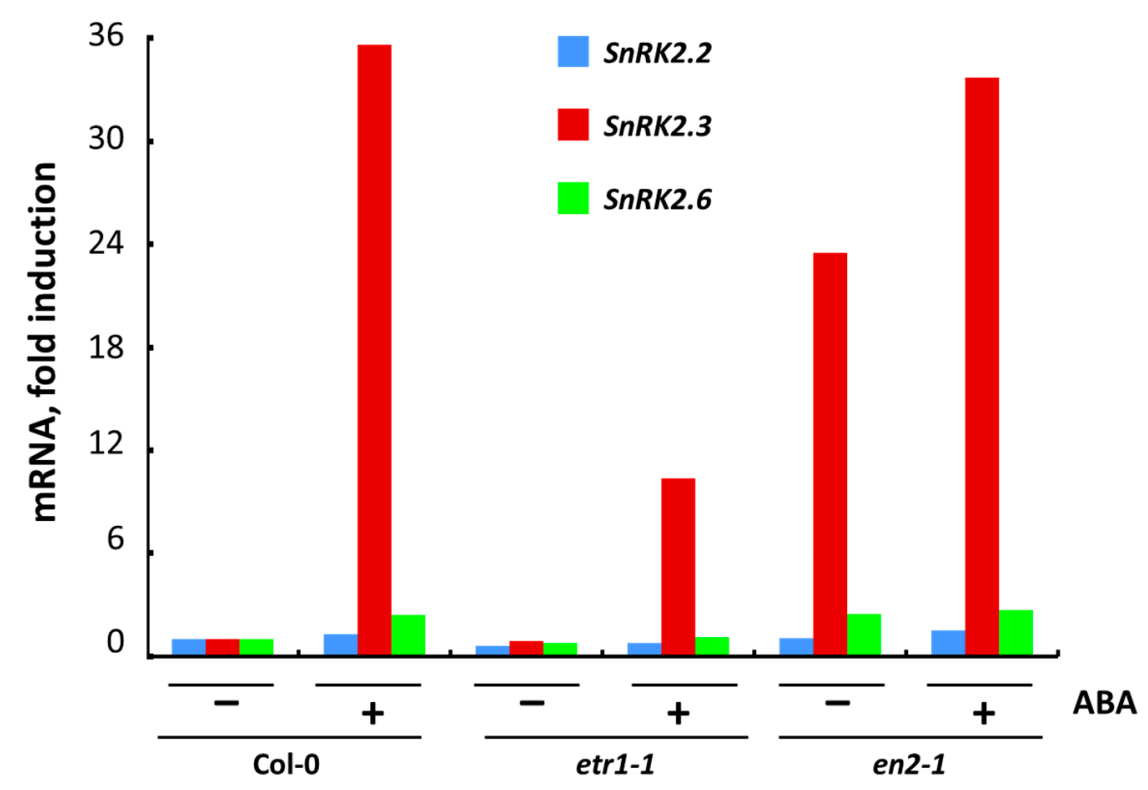

Figure 5. Expression of individual genes coding for $S n R K 2 \mathrm{~s}$ in Col-0, etr1-1 and ein2-1 cultures after $3 \mathrm{~h}$ treatment with ABA, estimated by RT-PCR with At $A C T 2$ as a reference gene. Results of a typical experiment are presented.

In ein2-1, a high level of expression of all SnRK2 in the control may indicate that a point mutation in the EIN2 gene leads to a constitutive functioning of the ABA signaling pathway. Apparently, this can be associated with the hypersensitivity of ein 2 mutants to ABA $[27,28,65]$. Taking into account that the endogenous ABA content is similar in Col-0, etr1-1 and ein2-1 cells, the observed changes in the expression of $S n R K 2.2 / 2.3 / 2.6$ were probably due to exogenous ABA application.

In the literature, it has been established that etr1-1 and ein2-1 display an increased sensitivity to ABA in comparison to Col-0, at least during seed germination and early seedling growth $[5,27]$. To what extent is the physiological response to ABA consistent with the function of the ABA signal transduction pathway? Our analysis of $S n R K 2.2 / 2.3 / 2.6$ expression suggests that, in unstressed cells, 
the change in the fate of cultured cells-active proliferation or terminal differentiation-cannot be explained by only the activity of ABA signaling pathway. It must be also dependent on the functional activity of both ethylene receptors and the components of the ethylene signal transduction pathway.

\subsection{The effect of ABA on MAPK Activity in Col-0 and Ethylene-Insensitive Mutant Cell Cultures}

Since the preferable MPKs' in vitro substrate is myelin basic protein (MBP), we decided to use isoelectric focusing under native conditions. In order to enrich protein fractions with MPKs we used isoelectric focusing under native conditions. Cytosolic proteins isolated from cells were fractionated using MicroRotofor Liquid-Phase IEF Cell, which allows the enrichment of low-abundance proteins [66] to enhance the results from downstream applications.

After focusing, 10 protein fractions with a $\mathrm{pH}$ range from 5.0 to 7.0 were obtained for proteins isolated from untreated and ABA-treated cell cultures of each genotype (Figure 6). In Col-0, in the fraction with $\mathrm{pH}$ 5.1, the MBP phosphorylation, a preferable MPKs in vitro substrate, decreased, and in the fraction with $\mathrm{pH} 6.2$ it increased after treatment with ABA. In etr1-1, the level of ABA-dependent MBP phosphorylation decreased in both fractions, and, in ein2-1, the level of MBP phosphorylation was increased after ABA treatment in both fractions. Thus, we focused on these fractions.

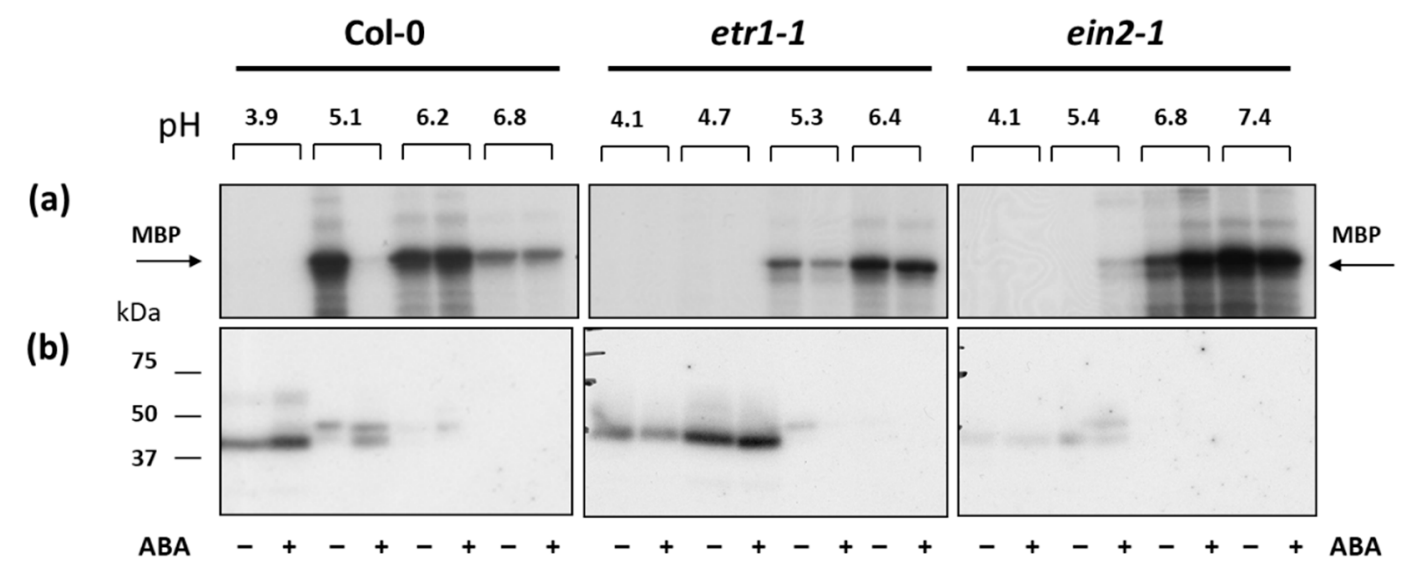

Figure 6. The effect of $\mathrm{ABA}(25 \mu \mathrm{M})$ on the MBP phosphorylation in vitro (a) and in gel (in situ) (b) in protein fractions enriched with low-abundance proteins using a MicroRotofor IEF Cell. Radioautographic image is presented.

In order to characterize further the proteins associated with MBP-kinase activity, proteins were electrophoresed and renaturated within the gel prior to phosphorylation with radiolabeled ATP (a typical autoradiograph is shown in Figure 6b). MBP-phosphorylating activity was associated with proteins of $\mathrm{Mr} \sim 41 \mathrm{kDa}$ and $\mathrm{Mr} \sim 45 \mathrm{kDa}$ in both Col-0 and mutant cell lines. Phosphorylation of 41-kDa polypeptide was promoted by ABA treatment in Col-0 (fractions with $\mathrm{pH}$ 5.1-5.4), while in ein2-1 the 45-kDa MBP-kinase was activated. This suggests that, depending on the functional activity of the ethylene signaling pathway, different individual MPKs are activated in response to ABA.

\subsection{Identification of MAPKs and Their Putative Substrates with MALDI-TOF MS}

To obtain a more detailed picture of the effect of ABA on protein kinase activity, we performed in vitro phosphorylation reaction (without an exogenous substrate) with protein fractions which exhibited MPK activity. For each genotype, groups of phosphoproteins specific for both ABA-treated and control cells were identified. For most proteins, their phosphorylation level significantly decreased after ABA treatment (Figure 7). 
(a)

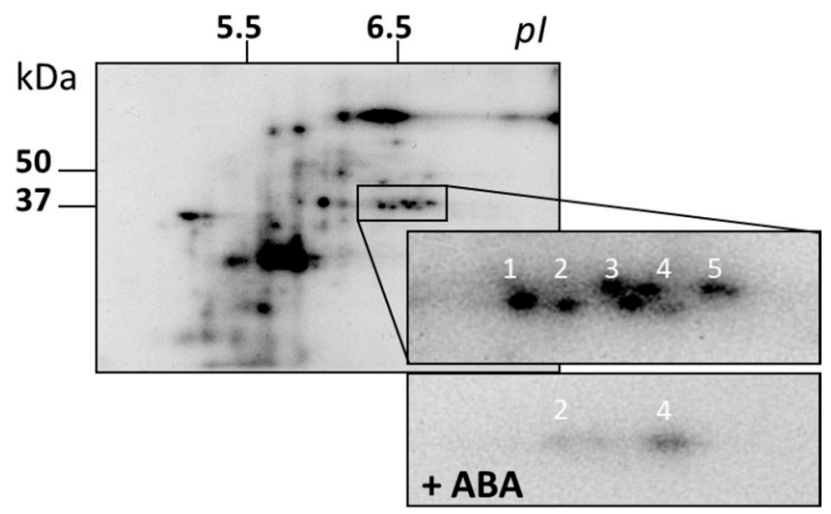

(b)

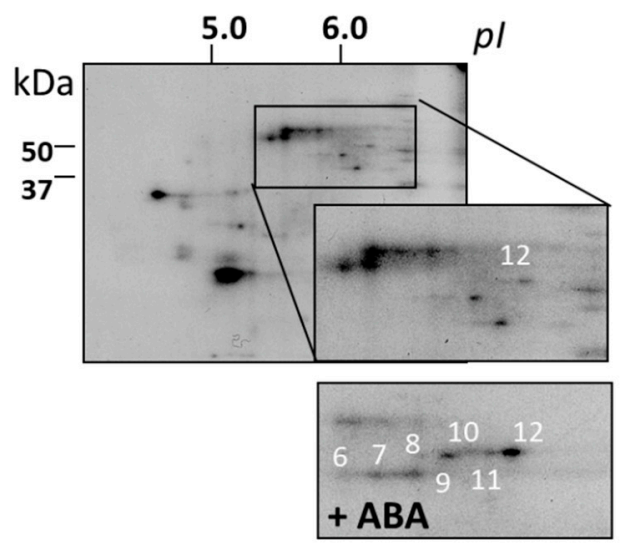

Figure 7. Radioautographic images of 2D-gels of the ABA-dependent phosphorylated proteins separated and enriched in the MicroRotofor IEF Cell. Fractions with pH 5.2 - 5.4 (a) and 6.2 - 6.8 (b) were used for 2D-gels ( $7 \mathrm{~cm}$ strips, $\mathrm{pH} 4.0-7.0$ ). The proteins identified by MALDI-TF MS are numbered.

For all cell lines, we selected 12 individual phosphoproteins for identification by finger prints. The following proteins were identified: NADP-dependent oxidoreductase (spot 1), annexin2 (ANNAT2, spot 2), aldo/ketoreductase (spot 3), PYL8 (spot 4), glyceraldehyde-3-phosphate dehydrogenase (spot 5), KRP4 (Kip-related protein, spot 6), two enolases (spots 7, 9), ATP synthase $\beta$-subunit (spot 8), translation initiation factor 4A (eF4A, spot10), MPK11 (spot 11), transcription factor SCL9 (from Scarecrow-like 9, spot 12) (Table 4 and Figure 7). The phosphorylation of proteins from spots 1, 2, 3, and 5 was lower in ABA-treated cells, whereas the phosphorylation level of the rest of proteins was higher. We analyzed the sequences of these proteins in the NetPhos and NetPhosK databases, and found that in some of the identified proteins, namely, in KRP4 (spot 6), eIF4A (spot 10), and SCL9 (spot 12), there are PX(S/T)P motifs present. These motifs could be phosphorylated by MPKs. In other words, it is quite possible that proteins with these motifs are potential substrates of MPKs. However, it cannot be ruled out that other protein kinases could carry out ABA-dependent phosphorylation of these proteins. For example, it has been shown that some substrates of MPK3/6 can be phosphorylated by CaM kinase II $\left(\mathrm{Ca}^{2+} /\right.$ Calmodulin dependent kinase II), PKC (Protein kinase C), and MAPKAPK2 (MAPK activated protein kinase 2) [67].

The protein MPK11 (spot 11) is one of the most interesting proteins out of all identified. The closest homolog of MPK11 is MPK4 [68]. To further confirm the identification of the phosphorylated form of MPK11, we concentrated the trypsin-digested protein spot 11 using magnetic beads coated with $\mathrm{TiO}_{2}$, then applied a strong anion exchanger (Polysulfoethyl A SCX) and subjected the sample to LC-ESI MS/MS. Thus, MRK11 was reliably determined by two different MS procedures.

Based on the literature data for identified proteins, their potential role in cell division and/or differentiation can be suggested. SCL9 transcription factor is of a special interest, since in Arabidopsis 
roots SCRs are shown to accumulate in the quiescent center and regulate asymmetric cell division [69-71]. Ethylene treatment increases the number of cells in the quiescent center of the wild-type Arabidopsis root and ctr1-1 [20]. Since, in our work, ABA caused an increase in DNA synthesis in etr1-1, both ethylene and ABA could be considered as signals for SCL9 phosphorylation.

Table 4. List of phosphorylated proteins identified by MALDI-TOF MS *.

\begin{tabular}{lcc}
\hline \multicolumn{1}{c}{ Protein } & pI & $\mathbf{M}_{\mathbf{r}}, \mathbf{D a}$ \\
\hline NADP-dependent oxidoreductase (spot 1) & 5.8 & 38133 \\
Annexin (ANNAT2) (spot 2) & 5.76 & 36243 \\
Aldo/keto reductase (spot 3) & 5.92 & 37900 \\
Pyrabactin resistance-like 8 (PYL8) (spot 4) & 6.07 & 21397 \\
Glyceraldehyde-3-phophate-dehydrogenase (spot 5) & 6.67 & 36913 \\
Kip-related protein 4 (KRP4) (spot 6) & 9.61 & 31699 \\
Enolase (spot 7) & 5.79 & 51477 \\
ATP synthase $\beta$-subunit (spot 8) & 6.18 & 59713 \\
Bifunctional enolase (spot 9) & 5.54 & 47689 \\
Translation initiation factor 4A (eF4A), (spot 10) & 5.47 & 46674 \\
Mitogen-activated protein kinase11 (MPK11) (spot 11) & 5.54 & 47689 \\
Scarecrow-like 9 (SCL9) (spot 12) & 5.66 & 53344 \\
\hline
\end{tabular}

* The entire list of protein characteristics is available in Supplementary Table S2.

The most often proposed scenario of stress-induced cell cycle inhibition assumes transcriptional upregulation of genes for cell cycle inhibitors such as cyclin-dependent kinase inhibitor $(\mathrm{ICK}) / \mathrm{KIP}$-related protein (KRP). These inhibitors are thought to transiently arrest cell proliferation by inhibiting CYCLIN-DEPENDENT KINASE A (CDKA)/cyclin complexes. CDKA activity, which is a main driver of the cell cycle progression, can also be reduced via targeted degradation of cyclins and/or inhibitory phosphorylation. ABA has been demonstrated to affect the expression of ICK/KRP. KRP4 protein, identified in our experiments, is one of the seven Arabidopsis KRP proteins. Previously, in a two-hybrid yeast system, it was shown that cyclin-cyclin-dependent protein kinase (CDK) complexes can interact with all Arabidopsis KRPs [71]. The phosphorylation of KRP is known to affect its binding to CDKA, and therefore affect the development of G1/S/G2 [72]. On the other hand, in the cells that underwent endoreduplication, the kinase activity of CDKB is decreased, and KRP can bind and inhibit CDKA [71]. In Arabidopsis, overexpression of KRP1 results in a reduction in both the number of endocycles and trichome cell size [73]. The peak of KRP4 expression occurs in the G2 phase [74], and the KRP4 protein is responsible for the correct progression via the $S$ phase [75].

In eukaryotes, the phosphorylation of translation initiation factor eIF4A leads to the increased assembly of polysomes and, as a result, to up-regulation of protein synthesis. Mammalian eIF4A is a substrate of MAPKAPK1, which is phosphorylated by ERK1 and JNK [76]. In mammals, MAPKAPK2 regulates the $S$ phase as well as G2/M in response to UV-C [77]. As far as we know, MAPKAPK1/2 has not yet been found in plants, but in Arabidopsis there are proteins containing PPR repeats (pentatricopeptide repeat-containing), as well as protein kinases with calmodulin-like domains, which have 38\% and 37\% homology with MAPKAPK1/2, respectively.

Of particular interest is the PYL8, a member of the ABA receptors family. We have shown that PYL8 is phosphorylated in Arabidopsis cells. Taking into account the mechanism of ABA signaling, the question arises, as to which state-phosphorylated or dephosphorylated-should the ABA receptor be in, in order to both bind ABA and initiate SnRK2 protein kinase cascade to enable signal transduction? Based on MS analysis data, we can assume that ABA-dependent protein phosphorylation is associated with the G1 and S phases. Our data are consistent with the Arabidopsis transcriptome, which shows that transcription of the genes encoding the proteins discussed above is also associated with cell division [78]. 


\section{Conclusion}

Here, we report the results of the initial study on a mechanism of control of plant cell proliferation and differentiation via interaction of ethylene and ABA signal transduction pathways. The cross-talk of ethylene and ABA signaling routes have been demonstrated upon seed germination $[3,4,79]$, stomata cells movement $[78,79]$, and changes in root growth, including the formation of lateral roots under heat stress $[80,81]$. However, based on these data, it is difficult to specify the effect of ethylene and ABA on cell division. At the same time, ethylene rather than auxin, is recognized as a positive regulator of cell proliferation. Ethylene enhances cell division in the quiescent center, which acts as a source of stem cells in the A. thaliana seedling root [20]. Although ABA is often considered as a growth inhibitor hormone, there is an evidence that $\mathrm{ABA}$ at low concentrations can activate growth $[27,28]$.

Using suspension tissue cultures of A. thaliana Col-0, as well as ethylene-insensitive mutants etr1-1, ctr1-1, and ein2-1, we were able to show that ethylene and ABA do not influence the biosynthesis of each other (Table 2; Table 3). Indeed, a short-term treatment with exogenous ABA did not significantly enhance ethylene emission. During cell cultivation, however, Col-0 cells evolved ethylene in quantities sufficient for continuous cell division. It seems likely that the interaction of ethylene and ABA is associated with the regulation of the target genes' expression.

The binding of exogenous ABA to the corresponding receptor(s) leads to the interaction of the protein phosphatase PP2C with the hormone-receptor complex and to the inactivation of SnRK2 kinases. As a result, protein kinases SnRK2s are released from PP2C inhibition. Being autoactivated, SnRK2s execute ABA-dependent phosphorylation of their targets. Among them, there may be MPKs that are involved in ABA-mediated reduction in proliferation by activation of KRP4, as we identified in this work.

In cell cultures, ethylene is a mitogen, but the mechanism of its action has been poorly understood. Downstream of ethylene receptors, the MAP kinase module with AtMPK3/6 operates [43]. In response to ethylene, expression of PP2C genes is enhanced [82] because PP2C subgroup B and some representatives of subgroup A have domains that ensure their binding to MPK, including MPK6 [82]. The binding of PP2C to MPK6 leads to a decrease in MPK6 activity, and, as a result, autoregulation of ethylene biosynthesis can occur to allow cells to proliferate.

This study provides the evidence for the ethylene-ABA interaction while regulating cell division and differentiation as follows (Figure 8). When the ethylene signal transduction pathway is functionally active (Col-0), the cells actively proliferate, and exogenous ABA performs its function as an inhibitor of DNA synthesis and division. If ethylene signal is not perceived (etr1-1), then, in addition to differentiation (TE formation), cell death can occur, and exogenous ABA rescues the cells, increasing proliferation. If the ethylene signal is perceived, but not transduced (ein2-1), then differentiation takes place, which is enhanced by exogenous ABA, while cell proliferation is reduced. When the transduction chain is constitutively active, the cells begin to exit the cell cycle and proceed to endoreduplication (ctr1-1). In this case, exogenous ABA promotes the reactivation of cell division.

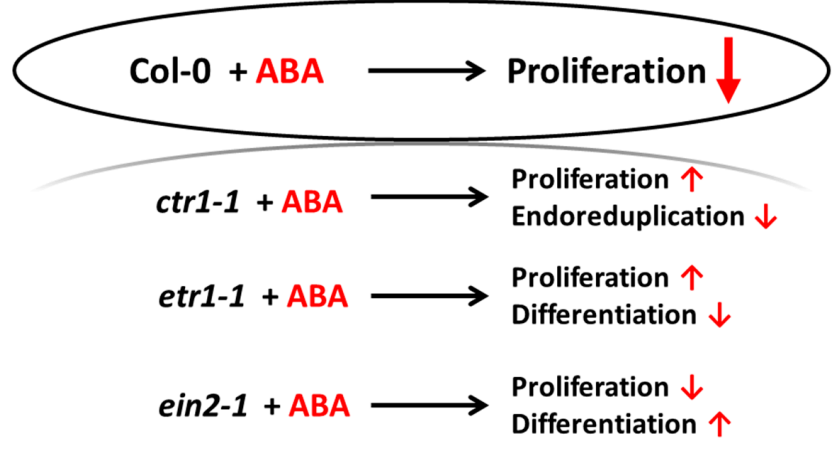

Figure 8. Schematic representation of the cellular events occurring in cultured Arabidopsis cells treated with ABA. 
Thus, the perception and transduction of the ethylene signal determines the ratio of cell proliferation and differentiation/death, which can be adjusted by ABA. Apparently, in the absence of ethylene perception, the underlying mechanism(s) is different from those accompanying aging.

Supplementary Materials: Supplementary materials can be accessed at http:/www.mdpi.com/2075-1729/10/2/15/s1. Author Contributions: G.V.N. designed and supervised most of the experiments and contributed to the writing of the paper; A.V.N. contributed to the design of the experiments; N.S.S. provided technical support in maintaining of cell cultures and figure preparation; A.A.Z. undertook the RT-PCR experiments; V.Y.R. undertook ethylene and ABA measurements; I.E.M. analyzed the proteomics data; D.A.L. supervised most of the experiments and contributed to the writing of the paper. All authors have read and agreed to the published version of the manuscript.

Funding: This research was funded by the Russian Science Foundation (grant no 14-24-00020 for G.V.N., A.A.Z., and D.A.L.) and Russian Foundation for Basic Research (grant nos. 11-04-01006, 11-04-01509, and 11-04-01225 for N.S.S., A.V.N., and V.Yu.R.), and by Ministry of Science and Higher Education of the Russian Federation (Project no. 0106-2019-0010) to D.A.L.

Acknowledgments: Authors are grateful to Maria Shumskaya (Kean University, NJ, USA) for her critical reading of the manuscript.

Conflicts of Interest: The authors declare no conflict of interest. The funders played no role in the design of the study; in the collection, analyses, or interpretation of data; in the writing of the manuscript; or in the decision to publish the results.

\section{References}

1. Dudits, D.; Abraham, E.; Miskolczi, P.; Ayaydin, F.; Bilgin, M.; Gabor, V.; Horvath, G.V. Cell-cycle control as a target for calcium, hormonal and developmental signals: the role of phosphorylation in the retinoblastoma-centered pathway. Ann. Bot. 2005, 107, 193-1202. [CrossRef]

2. Ruggiero, B.; Koiwa, H.; Manabe, Y.; Quist, T.M.; Inan, G.; Saccardo, F.; Joly, R.J.; Hasegawa, P.M.; Bressan, R.A.; Maggio, A. Uncoupling the effects of abscisic acid on plant growth and water relations. Analysis of sto1/nced3, an abscisic acid-deficient but salt stress-tolerant mutant in Arabidopsis. Plant Physiol. 2004, 136, 3134-3147. [CrossRef]

3. Beaudoin, N.; Serizet, C.; Gosti, F.; Giraudat, J. Interactions between abscisic acid and ethylene signaling cascades. Plant Cell 2000, 12, 1103-1116. [CrossRef]

4. Ghassemian, M.; Nambara, E.; Cutler, S.; Kawaide, H.; Kamiya, Y.; McCourt, P. Regulation of abscisic acid signaling by the ethylene response pathway in Arabidopsis. Plant Cell 2000, 12, 1117-1126. [CrossRef]

5. Wang, H.; Ngwenyama, N.; Liu, Y.; Walker, J.C.; Zhang, S. Stomatal development and patterning are regulated by environmentally responsive mitogen-activated protein kinases in Arabidopsis. Plant Cell 2007, 19, 63-73. [CrossRef]

6. Stepanchenko, N.S.; Fomenkov, A.A.; Moshkov, I.E.; Rakitin, V.Y.; Novikova, G.V.; Nosov, A.V. Phytohormone interplay controls proliferation of in vitro cultivated cells of Arabidopsis thaliana ethylene-insensitive mutants. Dokl. Biol. Sci. 2012, 442, 46-49. [CrossRef]

7. Ju, C.; Chang, C. Mechanistic insights in ethylene perception and signal transduction. Plant Physiol. 2015, 169, 85-95. [CrossRef] [PubMed]

8. Ma, Y.; Szostkiewicz, I.; Korte, A.; Moes, D.; Yang, Y.; Christmann, A.; Grill, E. Regulators of PP2C phosphatase activity function as abscisic acid sensors. Science 2009, 324, 1064-1068. [CrossRef]

9. Park, S.Y.; Fung, P.; Nishimura, N.; Jensen, D.R.; Fujii, H.; Zhao, Y.; Lumba, S.; Santiago, J.; Rodrigues, A.; Chow, T.F.; et al. Abscisic acid inhibits type $2 \mathrm{C}$ protein phosphatases via the PYR/PYL family of START proteins. Science 2009, 324, 1068-1071. [CrossRef] [PubMed]

10. Soon, F.F.; Ng, L.-M.; Zhou, X.E.; West, G.M.; Kovach, A.; Tan, M.H.; Suino-Powell, K.M.; He, Y.; Xu, Y.; Chalmers, M.J.; et al. Molecular mimicry regulates ABA signaling by SnRK2 kinases and PP2C phosphatases. Science 2012, 335, 85-88. [CrossRef] [PubMed]

11. Fujii, H.; Zhu, J.K. Arabidopsis mutant deficient in 3 abscisic acid-activated protein kinases reveals critical roles in growth, reproduction, and stress. Proc. Natl. Acad. Sci. USA 2009, 106, 8380-8385. [CrossRef] [PubMed] 
12. Fujita, Y.; Nakashima, K.; Yoshida, T.; Katagiri, T.; Kidokoro, S.; Kanamori, N. Three SnRK2 protein kinases are the main positive regulators of abscisic acid signaling in response to water stress in Arabidopsis. Plant Cell Physiol. 2009, 50, 2123-2132. [CrossRef] [PubMed]

13. Nakashima, K.; Nakashima, K.; Fujita, Y.; Kanamori, N.; Katagiri, T.; Umezawa, T.; Kidokoro, S.; Maruyama, K.; Yoshida, T.; Ishiyama, K.; et al. Three Arabidopsis SnRK2 protein kinases, SRK2D/SnRK2.2, SRK2E/SnRK2.6/OST1 and SRK2I/SnRK2.3, involved in ABA signaling are essential for the control of seed development and dormancy. Plant Cell Physiol 2009, 50, 1345-1363. [CrossRef] [PubMed]

14. Cutler, S.R.; Rodriguez, P.L.; Finkelstein, R.R.; Abrams, S.R. Abscisic acid: emergence of a core signaling network. Annu. Rev. Plant Biol. 2010, 61, 651-679. [CrossRef] [PubMed]

15. Yoshida, T.; Fujita, Y.; Sayama, H.; Kidokoro, S.; Maruyama, K.; Mizoi, J.; Yamaguchi-Shinozaki, K. AREB1, AREB2, and ABF3 are master transcription factors that cooperatively regulate ABRE-dependent ABA signaling involved in drought stress tolerance and require ABA for full activation. Plant J. 2010, 61, 672-685. [CrossRef] [PubMed]

16. Harashima, H.; Dissmeyer, N.; Schnittger, A. Cell cycle control across the eukaryotic kingdom. Trends Cell Biol. 2013, 23, 345-356. [CrossRef]

17. Apelbaum, A.; Burg, S. Effect of ethylene on cell division and deoxyribonucleic acid synthesis in Pisum sativum. Plant Physiol. 1972, 50, 117-124. [CrossRef]

18. Herbert, R.J.; Vilhar, B.; Evett, C.; Orchard, C.B.; Rogers, H.J.; Davies, M.S.; Francis, D. Ethylene induces cell death at particular phases of the cell cycle in the tobacco TBY-2 cell line. J. Exp. Bot. 2001, 52, 1615-1623.

19. Dan, H.; Imaseki, H.; Wasteneys, G.O.; Kazama, H. Ethylene stimulates endoreduplication but inhibits cytokinesis in cucumber hypocotyl epidermis. Plant Physiol. 2003, 133, 1726-1731. [CrossRef]

20. Ortega-Martenez, O.; Pernas, M.; Carol, R.J.; Dolan, L. Ethylene modulates stem cell division in the Arabidopsis thaliana root. Science 2007, 317, 507-510. [CrossRef]

21. Love, J.; Bjorklund, S.; Vahala, J.; Hertzberg, M.; Kangasjarvi, J.; Sundberg, B. Ethylene is an endogenous stimulator of cell division in the cambial meristem of Populus. Proc. Natl. Acad. Sci. USA 2009, 106, 5984-5989. [CrossRef] [PubMed]

22. Bystrova, E.I.; Zhukovskaya, N.V.; Rakitin, V.Y.; Ivanov, V.B. Role of ethylene in activation of cell division in quiescent center of excised maize roots. Rus. J. Dev. Biol. 2015, 46, 60-64. [CrossRef]

23. Swiatek, A.; Lenjou, M.; van Bockstaele, D.; Inze, D.; van Onckelen, H. Differential effect of jasmonic acid and abscisic acid on cell cycle progression in tobacco BY-2 cells. Plant Physiol. 2002, 128, 201-211. [CrossRef] [PubMed]

24. Skirycz, A.; Claeys, H.; De Bodt, S.; Oikawa, A.; Shinoda, S.; Andriankaja, M.; Maleux, K.; Eloy, N.B.; Coppens, F.; Yoo, S.-D.; et al. Pause-and-stop: The effects of osmotic stress on cell proliferation during early leaf development in Arabidopsis and a role for ethylene signaling in cell cycle arrest. Plant Cell 2011, 23, 1876-1888. [CrossRef]

25. Meszaros, T.; Miskolczi, P.; Ayaydin, F.; Pettko-Szandtner, A.; Peres, A.; Magyar, Z.; Horvath, G.V.; Bako, L.; Feher, A.; Dudits, D. Multiple cyclin-dependent kinase complexes and phosphatases control G2/M progression in alfalfa cells. Plant Mol. Biol. 2000, 43, 595-605. [CrossRef]

26. West, G.; Inze, D.; Beemster, G.T. Cell cycle modulation in the response of the primary root of Arabidopsis to salt stress. Plant Physiol. 2004, 135, 1050-1058. [CrossRef]

27. Cheng, W.H.; Endo, A.; Zhou, L.; Penney, J.; Chen, H.-C.; Arroyo, A.; Leon, P.; Nambara, E.; Asami, T.; Seo, M.; et al. A unique short-chain dehydrogenase/reductase in Arabidopsis glucose signaling and abscisic acid biosynthesis and functions. Plant Cell 2002, 14, 2723-2743. [CrossRef]

28. Sharp, R.E.; LeNoble, M.E.; Else, M.A.; Thorne, E.T.; Gherardi, F. Endogenous ABA maintains shoot growth in tomato independently of effects on plant water balance: evidence for an interaction with ethylene. J. Exp. Bot. 2000, 51, 1575-1584. [CrossRef]

29. Shenk, R.U.; Hildebrandt, A. Medium and techniques for induction and growth of monocotyledons and dicotyledons plant cell cultures. Can. J. Bot. 1972, 50, 199-204. [CrossRef]

30. Sato, Y.; Yajima, Y.; Tokunaga, N.; Whetten, R. Comparison between tracheary element lignin formation and extracellular lignin-like substance formation during the culture of isolated Zinnia elegans mesophyll cells. Biologia 2011, 66, 88-95. [CrossRef]

31. Ueda, J.; Saito, H.; Watanabe, H.; Evers, B.M. Novel and quantitative DNA dot-blotting methods for assessment of in vivo proliferation. Am. J. Physiol. 2005, 288, 842-847. [CrossRef] [PubMed] 
32. Fomenkov, A.A.; Nosov, A.V.; Rakitin, V.Y.; Sukhanova, E.S.; Mamaeva, A.S.; Sobol'kova, G.I.; Nosov, A.M.; Novikova, G.V. Ethylene in the proliferation of cultured plant cells: Regulating or just going along? Rus. J. Plant Physiol. 2015, 62, 815-822. [CrossRef]

33. Novikova, G.V.; Mur, L.A.J.; Nosov, A.V.; Fomenkov, A.A.; Mironov, K.S.; Mamaeva, A.S.; Shilov, E.S.; Rakitin, V.Y.; Hall, M.A. Nitric oxide has a concentration-dependent effect on the cell cycle acting via EIN2 in Arabidopsis thaliana cultured cells. Front. Physiol. 2017, 8, 142. [CrossRef]

34. Laemmli, U.K. Cleavage of structural proteins during the assembly of the head of bacteriophage T4. Nature 1970, 227, 680-685. [CrossRef]

35. Shevchenko, A.; Wilm, M.; Vorm, O.; Mann, M. Mass spectrometric sequencing of proteins from silver-stained polyacrylamide gels. Anal. Chem. 1996, 68, 850-858. [CrossRef]

36. Hey, J.; Posch, A.; Cohen, A.; Liu, N.; Harbers, A. Fractionation of complex protein mixtures by liquid-phase isoelectric focusing. Methods Mol. Biol. 2008, 424, 225-239. [CrossRef]

37. Neuhoff, V.; Stamm, R.; Eibl, H. Clear background and highly sensitive protein staining with Coomassie Blue dyes in polyacrylamide gels: a systematic analysis. Electrophoresis 1985, 6, 427-448. [CrossRef]

38. Fomenkov, A.A.; Nosov, A.V.; Rakitin, V.Y.; Mamaeva, A.S.; Novikova, G.V. Cytophysiological characteristics of Arabidopsis thaliana cultivated cells with disable perception of ethylene signal by the ETR1 receptor. Rus. J. Plant Physiol. 2014, 61, 598-607. [CrossRef]

39. Oda, Y.; Fukuda, H. Secondary cell wall patterning during xylem differentiation. Curr. Opin. Plant Biol. 2012, 15, 38-44. [CrossRef]

40. Oda, Y.; Mimura, T.; Hasezawa, S. Regulation of secondary cell wall development by cortical microtubules during tracheary element differentiation in Arabidopsis cell suspensions. Plant Physiol. 2005, 137, 1027-1036. [CrossRef]

41. Novikova, G.V.; Moshkov, I.E.; Smith, A.R.; Hall, M.A. The effect of ethylene on MAPKinase-like activity in Arabidopsis thaliana. FEBS Lett. 2000, 474, 29-32. [CrossRef]

42. Ouaked, F.; Rozhon, W.; Lecourieux, D.; Hirt, H. A MAPK pathway mediates ethylene signaling in plants. EMBO J. 2003, 22, 1282-1288. [CrossRef] [PubMed]

43. Yoo, S.-D.; Cho, Y.-H.; Tena, G.; Xiong, Y.; Sheen, J. Dual control of nuclear EIN3 by bifurcate MAPK cascades in $\mathrm{C}_{2} \mathrm{H}_{4}$ signalling. Nature 2008, 451, 789-797. [CrossRef] [PubMed]

44. Liu, Y. Roles of mitogen-activated protein kinase cascades in ABA signaling. Plant Cell Rep. 2012, 31, 1-12. [CrossRef] [PubMed]

45. de Zelicourt, A.; Colcombet, J.; Hirt, H. The role of MAPK modules and ABA during abiotic stress signaling. Trends Plant Sci. 2016, 21, 677-685. [CrossRef] [PubMed]

46. Jagodzik, P.; Tajdel-Zielinska, M.; Ciesla, A.; Marczak, M.; Ludwikow, A. Mitogen-activated protein kinase cascades in plant hormone signaling. Front. Plant Sci. 2018, 9, 1387. [CrossRef] [PubMed]

47. Sasabe, M.; Boudolf, V.; De Veylder, L.; Inze, D.; Genschik, P.; Machida, Y. Phosphorylation of a mitotic kinesin-like protein and a MAPKKK by cyclin-dependent kinases (CDKs) is involved in the transition to cytokinesis in plants. Proc. Natl. Acad. Sci. USA 2011, 108, 17844-17849. [CrossRef]

48. Fujita, M.; Fujita, Y.; Noutoshi, Y.; Takahashi, F.; Narusaka, Y.; Yamaguchi-Shinozaki, K.; Shinozaki, K. Crosstalk between abiotic and biotic stress responses, a current view from the points of convergence in the stress signaling networks. Curr. Opin. Plant Biol. 2006, 9, 436-442. [CrossRef]

49. Xing, Y.; Jia, W.; Zhang, J. AtMKK1 mediates ABA-induced CAT1 expression and $\mathrm{H}_{2} \mathrm{O}_{2}$ production via AtMPK6-coupled signaling in Arabidopsis. Plant J. 2008, 54, 440-451. [CrossRef]

50. Zhang, H.; Zhu, H.; Pan, Y.; Yu, Y.; Luan, S.; Li, L. A DTX/MATE-type transporter facilitates abscisic acid efflux and modulates ABA sensitivity and drought tolerance in Arabidopsis. Mol. Plant 2014, 7, 1522-1532. [CrossRef]

51. Zhang, J.; Zou, D.; Li, Y.; Sun, X.; Wang, N.N.; Gong, S.Y.; Zheng, Y.; Li, X.-B. GhMPK17, a cotton mitogen-activated protein kinase, is involved in plant response to high salinity and osmotic stresses and ABA signaling. PLoS ONE 2014, 9, e95642. [CrossRef] [PubMed]

52. Li, Y.; Cai, H.; Liu, P.; Wang, C.; Gao, H.; Wu, C.; Yan, K.; Zhang, S.; Huang, J.; Zheng, C. Arabidopsis MAPKKK18 positively regulates drought stress resistance via downstream MAPKK3. Biochem. Biophys. Res. Commun. 2017, 484, 292-297. [CrossRef] [PubMed] 
53. Li, K.; Yang, F.; Zhang, G.; Song, S.; Li, Y.; Ren, D.; Miao, Y.; Song, C.-P. AIK1, a mitogen-activated protein kinase, modulates abscisic acid responses through the MKK5-MPK6 kinase cascade. Plant Physiol. 2017, 173, 1391-1408. [CrossRef] [PubMed]

54. Li, Q.; Wang, Y.; Liu, C.; Pei, Z.M.; Shi, W.-L. The crosstalk between ABA, nitric oxide, hydrogen peroxide, and calcium in stomatal closing of Arabidopsis thaliana. Biologia 2017, 72, 1140-1146. [CrossRef]

55. MAPK Group. Mitogen-activated protein kinase cascades in plants: A new nomenclature. Trends Plant Sci. 2002, 7, 301-308. [CrossRef]

56. Ortiz-Masia, D.; Perez-Amador, M.A.; Carbonell, J.; Marcote, M.J. Diverse stress signals activate the C1 subgroup MAP kinases of Arabidopsis. FEBS Lett. 2007, 581, 1834-1840. [CrossRef]

57. Kobayashi, Y.; Yamamoto, S.; Minami, H.; Kagaya, Y.; Hattori, T. Differential activation of the rice sucrose nonfermenting 1- related protein kinase 2 family by hyperosmotic stress and abscisic acid. Plant Cell 2004, 16, 1163-1177. [CrossRef]

58. Mustilli, A.C.; Merlot, S.; Vavasseurb, A.; Fenzia, F.; Giraudat, J. Arabidopsis OST1 protein kinase mediates the regulation of stomatal aperture by abscisic acid and acts upstream of reactive oxygen species production. Plant Cell 2002, 14, 3089-3099. [CrossRef]

59. Yoshida, R.; Hobo, T.; Ichimura, K.; Mizoguchi, T.; Takahashi, F.; Aronso, J.; Ecker, J.R.; Shinozaki, K. ABA-activated SnRK2 protein kinase is required for dehydration stress signaling in Arabidopsis. Plant Cell Physiol. 2002, 43, 1473-1483. [CrossRef]

60. Hrabak, E.M.; Chan, C.W.M.; Gribskov, M.; Harper, J.F.; Choi, J.H.; Halford, N.; Kudla, J.; Luan, S.; Nimmo, H.G.; Sussman, M.R.; et al. The Arabidopsis CDPK-SnRK superfamily of protein kinases. Plant Physiol. 2003, 132, 666-680. [CrossRef]

61. Boudsocq, M.; Barbier-Brygoo, H.; Laurière, C. Identification of nine sucrose nonfermenting 1-related protein kinases 2 activated by hyperosmotic and saline stresses in Arabidopsis thaliana. J. Biol. Chem. 2004, 279, 41758-41766. [CrossRef]

62. Yoshida, R.; Umezawa, T.; Mizoguchi, T.; Takahashi, S.; Takahashi, F.; Shinozaki, K. The regulatory domain of SRK2E/OST1/SnRK2.6 interacts with ABI1 and integrates abscisic acid (ABA) and osmotic stress signals controlling stomatal closure in Arabidopsis. J. Biol. Chem. 2006, 281, 5310-5318. [CrossRef]

63. Righetti, P.G.; Castagna, A.; Herbert, B.; Candiano, G. How to bring the "unseen" proteome to the limelight via electrophoretic pre-fractionation techniques. Biosci. Rep. 2005, 25, 3-17. [CrossRef] [PubMed]

64. Taj, G.; Agarwal, P.; Kumar, A. In-silico approaches for studying cross-talk of different kinases associated in diverse biological processes with their interacting substrates partners. J. Proteomics Bioinform. 2011, 4, 91-97. [CrossRef]

65. Kosetsu, K.; Matsunaga, S.; Nakagami, H.; Colcombet, J.; Sasabe, M.; Soyano, T.; Takahashi, Y.; Hirt, H.; Machida, Y. The MAP kinase MPK4 is required for cytokinesis in Arabidopsis thaliana. Plant Cell 2010, 22, 3778-3790. [CrossRef] [PubMed]

66. Di Laurenzio, L.; Wysocka-Diller, J.; Malamy, J.E.; Pysh, L.; Helariutta, Y.; Freshour, G.; Hahn, M.G.; Feldmann, K.A.; Benfey, P.N. The SCARECROW gene regulates an asymmetric cell division that is essential for generating the radial organization of the Arabidopsis root. Cell 1996, 86, 423-433. [CrossRef]

67. Wysocka-Diller, J.; Helariutta, Y.; Hukaki, H.; Malamy, J.; Benfey, P.N. Molecular analysis of SCARECROW functions reveals a radial patterning mechanism common to root and shoot. Development 2000, 127, 595-603.

68. Heidstra, R.; Welch, D.; Scheres, B. Mosaic analysis using marked activation and deletion clones dissect Arabidopsis SCARECROW action in asymmetric cell division. Genes Dev. 2004, 18, 1964-1969. [CrossRef]

69. Nakai, T.; Kato, K.; Shinmyo, A.; Sekine, M. Arabidopsis KRPs have distinct inhibitory activity toward cyclin D2-associated kinases, including plant-specific B-type cyclin-dependent kinase. FEBS Lett. 2006, 580, 336-340. [CrossRef]

70. Verkest, A.; Manes, C.L.D.; Vercruysse, S.; Maes, S.; Van der Schueren, E.; Beekman, R.T.; Genschik, P.; Kuiper, M.; Inze, D.; De Veylder, I. The cyclin-dependent kinase inhibitor KRP2 controls the onset of the endoreduplication cycle during Arabidopsis leaf development through inhibition of mitotic CDKA;1 kinase complexes. Plant Cell 2005, 17, 1723-1736. [CrossRef]

71. Schnittger, A.; Weinl, C.; Bouyer, D.; Schöbinger, U.; Hülskamp, M. Misexpression of the cyclin-dependent kinase inhibitor ICK1/KRP1 in single-celled Arabidopsis trichomes reduces endoreduplication and cell size and indices cell death. Plant Cell 2003, 15, 303-315. [CrossRef] [PubMed] 
72. Menges, M.; de Jager, S.M.; Gruissem, W.; Murray, J.A.H. Global analysis of the core cell cycle regulators of Arabidopsis identifies novel genes, reveals multiple and highly specific profiles of expression and provides a coherent model for plant cell cycle control. Plant J. 2005, 41, 546-566. [CrossRef] [PubMed]

73. Ormenese, S.; de Almeida Engler, J.; De Groodt, R.; De Veylder, L.; Inzé, D.; Jacqmard, A. Analysis of the spatial expression pattern of seven Kip related proteins (KRPs) in the shoot apex of Arabidopsis thaliana. Ann. Bot. 2004, 93, 575-580. [CrossRef] [PubMed]

74. Neufeld, B.; Grosse-Wilde, A.; Hoffmeyer, A.; Jordan, B.W.; Chen, P.; Dinev, D.; Ludwig, S.; Rapp, U.R. Serine/Threonine kinases 3pK and MAPK-activated protein kinase 2 interact with the basic helix-loop-helix factor E47 and repress its transcriptional activity. J. Biol. Chem. 2000, 275, 20239-20242. [CrossRef] [PubMed]

75. Manke, I.A.; Nguyen, A.; Lim, D.; Stewart, M.Q.; Elia, A.E.H.; Yaffe, M.B. MAPKAP kinase-2 is a cell cycle checkpoint kinase that regulates the $\mathrm{G} 2 / \mathrm{M}$ transition and $\mathrm{S}$ phase progression in response to UV irradiation. Mol. Cell 2005, 17, 37-48. [CrossRef] [PubMed]

76. Menges, M.; Hennig, L.; Gruissem, W.; Murray, J.A.H. Cell cycle-regulated gene expression in Arabidopsis. J. Biol. Chem. 2002, 277, 41987-42002. [CrossRef]

77. Chiwocha, S.D.S.; Cutler, A.J.; Abrams, S.R.; Ambrose, S.J.; Yang, J.; Ross, A.R.S.; Kermode, A.R. The etr1-2 mutation in Arabidopsis thaliana affects the abscisic acid, auxin, cytokinin and gibberellin metabolic pathways during maintenance of seed dormancy, moist-chilling and germination. Plant J. 2005, 42, 35-48. [CrossRef]

78. Tanaka, Y.; Sano, T.; Tamaoki, M.; Nakajima, N.; Kondo, N.; Hasezawa, S. Ethylene inhibits abscisic acid-induced stomatal closure in Arabidopsis. Plant Physiol. 2005, 138, 2337-2343. [CrossRef]

79. Tanaka, Y.; Sano, T.; Tamaoki, M.; Nakajima, N.; Kondo, N.; Hasezawa, S. Cytokinin and auxin inhibit abscisic acid-induced stomatal closure by enhancing ethylene production in Arabidopsis. J. Exp. Bot. 2006, 57, 2259-2266. [CrossRef]

80. Sharp, R.E.; LeNoble, M.E. ABA, Ethylene and the control of shoot and root growth under water stress. J. Exp. Bot. 2002, 53, 33-37. [CrossRef]

81. Spollen, W.G.; LeNoble, M.E.; Samuels, T.D.; Bernstein, N.; Sharp, R.E. Abscisic acid accumulation maintains maize primary root elongation at low water potentials by restricting ethylene production. Plant Physiol. 2000, 122, 967-976. [CrossRef] [PubMed]

82. Schweighofer, A.; Kazanaviciute, V.; Scheikl, E.; Teige, M.; Doczi, R.; Hirt, H.; Schwanninger, M.; Kant, M.; Schuurink, R.; Mauch, F.; et al. The PP2C-type phosphatase AP2C1, which negatively regulates MPK4 and MPK6, modulates innate immunity, jasmonic acid, and ethylene levels in Arabidopsis. Plant Cell 2007, 19, 2213-2224. [CrossRef] [PubMed] 